Revista de Estudios Histórico-Jurídicos

[Sección historia de las instituciones]

XXXVIII (Valparaíso, Chile, 2016)

[pp. $445-470$ ]

\title{
CONFESIONALIDAD DEL ESTADO, REAL PATRONATO Y DERECHO CANÓNICO INDIANO EN LAS CORTES DE CÁdIZ
}

[The Confessional State, Royal Patronage and Indian Canon Law in the Courts of Cadiz]

\author{
Felipe Westermeyer Hernández* \\ Universidad de Chile, Santiago, Chile
}

\begin{abstract}
RESUMEN
AbSTRACT

El artículo indaga la pervivencia y el rol que jugaron el derecho canónico indiano y el real patronato en la redacción de la constitución de Cádiz de 1812, buscando la relación de ambos institutos con la cláusula de confesionalidad del Estado de la mentada carta fundamental.

Palabras Clave

Constitucionalismo gaditano - Derecho canónico indiano - Real patronato - confesionalidad del Estado.

This article is about the persistence and role of the Indian Canon Law and the royal patronage in the drafting of the constitution of Cadiz of 1812, aimed at finding the relationship between both institutions and the clause on Confessional State contained in said Constitution.

KeywOrds

Gaditan Constitution - Indian Canon Law - Royal Patronage-Confessional Sate.
\end{abstract}

ReCiBIDO el 29 de junio y ACEPTADO 30 de julio de 2016

* Licenciado en Ciencias Jurídicas y Sociales. Universidad de Chile. Abogado. Legum Magister in Rechtswissenschaft. Ruprecht-Karls-Universität Heidelberg. Ayudante de Historia del Derecho. Facultad de Derecho, Universidad de Chile. westermeyer.felipe@gmail.com El autor agradece el invaluable apoyo prestado por la bibliotecaria de esa unidad académica, señora Gioconda Pulgar. Del mismo modo, agradece las correcciones y sugerencias del profesor Antonio Dougnac Rodríguez. Todos los errores son única y exclusiva responsabilidad del autor. 


\section{INTRODUCCIÓN}

El surgimiento de los Estados nacionales en la Europa central y atlántica a partir de la baja edad media fue un proceso marcado por una fuerte impronta religiosa, tendencia que se acentuó a partir de la reforma del siglo XVI. "Una fe, una ley y un rey" sería la frase que sintetizaría la nueva organización europea tras el cisma del siglo XVI. La religión pasó a ser uno de los factores que daba identidad a las naciones europeas, fuese esta católica o protestante. Es así como en cada Estado se desarrollaron distintos modelos de cooperación entre la Iglesia y el Estado, como el real patronato en España y el Staatskirchentum ${ }^{1}$ en Alemania. Estos modelos pasaron a constituir un sistema: el Estado confesional, basado en la cooperación entre el poder temporal y él espiritual, con un mayor o menor control del primero sobre la vida religiosa de los súbditos. Al ser coetáneo a la reforma religiosa, el Estado confesional pasó a ser la expresión política y jurídica de la intolerancia religiosa.

Dicho sistema fue puesto en tela de juicio por la Ilustración. La independencia de las trece colonias norteamericanas y la revolución francesa implementaron nuevos modelos de relación entre Iglesia y Estado. En el primer caso se implementó un modelo basado en la libertad de culto, en el que todas las confesiones gozaban de un trato igualitario. En la Francia revolucionaria se fundó un Estado laico, con una política de abierta hostilidad hacia la Iglesia.

Ambos modelos, identificados con la primera etapa del Estado constitucional moderno, implicaban una ruptura con el Estado cristiano ${ }^{2}$. Dichos modelos significaron configurar una nueva relación entre el Estado, el individuo y la sociedad. Ambos reivindicaban la persona humana en cuanto individuo frente al Estado, enfocándose el primero en la libertad religiosa y el segundo en la libertad de conciencia y de pensamiento.

La adopción de cualquiera de esos modelos implicaba necesariamente reformular la relación entre la Iglesia y el Estado, por una parte, y buscar nuevos criterios para solucionar las colisiones entre los intereses y derechos del Estado, la sociedad y el individuo, por otra. Tal tarea se volvería una prioridad para los publicistas del siglo XIX.

\section{II. ¿QQUÉ PREGUNTAS DEJA SIN RESPONDER UN ANÁLISIS DEL artículo 12 de la CONSTITUCión de CÁdiz?}

Ante esta disyuntiva, el constituyente gaditano optó por darle carácter constitucional a la confesionalidad del Estado (art. 12). La fórmula gaditana, acorde

${ }^{1}$ Para una sucinta y clara explicación de este sistema véase CAMPENHAUSEN, Axel Freiherr von und De Wall, Heinrich Staatskirchenrecht ( $4^{\circ}$ Auflage, München, Verlag H. Beck, 2006), pp. 6-26.

2 La característica de esta primera etapa del Estado constitucional moderno es que la soberanía se sobrepone a la tradición. La idea es fundar algo nuevo. Véase FioraVANTI, Maurizio, Constitución. De la antigüedad a nuestros días (2001, 2a ed., Bolonia, Editorial Trotta. reimp, traducción castellana de Manuel Martínez Neira. Madrid, 2011). 
con lo expresado por el profesor Alberto de la Hera, implicó la identificación de la Constitución con todos los elementos definitorios del catolicismo; es decir, católico, apostólico y romano, la afirmación dogmática de ser el catolicismo la única religión verdadera, la obligación del legislador de prestarle protección a la Iglesia y una doble profesión de fe. Se reconoce a la divinidad como Dios uno y trino y en cuanto creador y legislador. Esta declaración implicaba forjar una relación de cooperación con el Vaticano, al menos en materia teológica y espiritual ${ }^{3}$.

Desde la perspectiva que da el largo tiempo, el profesor Bernardino Bravo agrega que el surgimiento del Estado constitucional, en cuanto Estado monocrático, no afecto al otro poder supremo de la constitución jurisdiccional: la Iglesia. Las cláusulas de confesionalidad del Estado implican el reconocimiento solemne y expreso no solo de una religión oficial, sino del real patronato y corroboran que los Estados sucesores mantuvieron el estatus jurídico de ese otro poder supremo sin mayores variaciones, a pesar de las dificultades y problemas derivados de la independencia ${ }^{4}$.

Agrega el profesor Bravo Lira que la fórmula de la religión oficial en las constituciones iberoamericanas se remonta a Carlos IV, en el pacto de abdicación de Bayona, reiterándose luego a uno y otro lado del Atlántico en gran parte de las protestas y manifestaciones de fidelidad a la monarquía ya la Iglesia. Estas cláusulas, junto con la reclamación del real patronato, son propias y originales del derecho constitucional de la América hispanoparlante 5 .

El tenor literal de dicha cláusula, modelo para diversas constituciones americanas $^{6}$, parece muy lejano a los modelos constitucionales actualmente vigentes en Occidente. Su simple lectura lleva a concluir que es una negación de la libertad religiosa. Pareciese que en las Cortes de Cádiz se impusieron los sectores más escépticos ante el constitucionalismo o, inclusive, que en cuanto a derecho eclesiástico los constituyentes gaditanos habrían obrado al margen de la doctrina constitucional en ese momento en boga.

Un análisis detallado de las reformas legales y las discusiones sostenidas en el seno de las Cortes da una opinión distinta. El constituyente gaditano optó por la vía del medio. Ni abrazó propuestas revolucionarias ni renunció a la posibilidad de introducir importantes reformas en la Iglesia y en la vida religiosa, fuese por medio de reformas en materia eclesiástica o como consecuencia de la fundación de un nuevo orden. Prueba de ello es la abolición de la Inquisición y la desamortización eclesiástica. Otras reformas como la introducción de una libertad de imprenta limitada, tocaron a la Iglesia.

En este trabajo pretendemos entrar en otra faceta. El real patronato indiano

${ }^{3}$ De la Hera, Alberto, El artículo 12 de la Constitución de Cádiz y la religión católica, en Escudero, José Antonio (ed.), Cortes y Constitución de Cádiz. 200 años (Madrid, Fundación Rafael del Pino, Editorial Espasa, 2011), II, pp. 695-709.

${ }^{4}$ Bravo Lira, Bernardino, Constitución y reconstitución. Historia del Estado en Iberoamérica (1511-2009), (Santiago de Chile, Abeledo Perrot LegalPublishing, 2010), pp. 69-70.

5 Ibíd., pp.69-70.

${ }^{6}$ El profesor Bravo Lira agrega como curiosidad que la proposición de Bolívar de prescindir de esa declaración fue rotundamente rechazada en 1826. 
y el derecho canónico indiano en las Cortes de Cádiz ${ }^{7}$ ¿Cómo se entendieron ambas instituciones en las Cortes? ¿Hubo propuestas de reformas al Estatuto de la Iglesia católica indiana? ¿Hubo algún reconocimiento a la especialidad del derecho canónico vigente en Indias respecto al europeo? ¿Renunciaron las Cortes a los objetivos evangelizadores del derecho indiano ${ }^{8}$ Partiendo de la base que efectivamente hubo cambios institucionales, ¡cómo se usó el derecho canónico indiano? ¿Fue abolido? ¿Se lo usó como base para introducir las mentadas reformas liberales? ¿Hubo una efectiva primacía de las ideas regalistas o se hicieron valer distintas interpretaciones de la relación entre la Iglesia y el Estado? ¿Hubo propuestas que propendiesen a la libertad de la Iglesia? ¿Qué significaba darle protección a la Iglesia?

Antes de intentar dar una respuesta a estas preguntas partiremos de tres su-

7 Importante es precisar la relación existente entre ambos. El real patronato se corresponde con lo que hoy día es el derecho eclesiástico, mientras el derecho canónico era y es un derecho de carácter confesional. En la época en estudio esa diferencia era todo menos clara. Por esa razón reproducimos el esquema conceptual formulado por el profesor Alberto de la Hera. El citado académico postula que el Estado dicta normas que integran su derecho eclesiástico de manera unilateral o de acuerdo con las confesiones religiosas. En el segundo caso se requiere que éstas gocen de reconocimiento jurídico. La vía normal de creación de derecho por esta vía son los concordatos. En ese caso las normas son a la vez confesionales y eclesiásticas. Puede ocurrir que estas toquen el fenómeno religioso de forma indiscutible y la confesión entienda que la actividad regulada posee un carácter confesional. Partiendo de este esquema conceptual, analizamos ambas instituciones en conjunto. En el derecho indiano las fronteras entre el derecho canónico y el eclesiástico son muy difusas. Lo mismo se apreciará en la definición de derecho canónico indiano de Justo Donoso, como se verá en las páginas siguientes. En los siglos de vigencia del derecho indiano el derecho canónico alcanzó plena validez en la vida interna de la Iglesia, en la vida espiritual de los fieles y en la regulación del matrimonio. En todas esas áreas, el Estado católico y misionero recibió las leyes de la Iglesia y les dio plena validez. A mayor abundamiento véase Dougnac Rodríguez; Antonio, Manual de historia del derecho indiano (2a edición, Mexico, McGraw-Hill, 1998), pp. 201-226; SánCHEZ Bella, Ismael, De la Hera, Alberto y Díaz de Rementería, Carlos, Historia del derecho indiano, en Colección Relaciones entre España y América (Madrid, Editorial Mapfre, 1992), p. 253 ss. El profesor chileno Carlos Salinas Araneda comparte ese criterio, empleando una definición amplia de derecho canónico indiano al momento de hacer una colactánea de los escritos acerca de esta rama de la historia del derecho. Al respecto véase, SALINAS ARANEDA, Carlos, Avance para una bibliografia chilena de historia del derecho indiano y El derecho canónico indiano en la bibliografía de una década: apuntes para un balance, ahora en ÉL MISMO, Estudios históricos. El Derecho canónico en Chile. Derecho canónico indiano (Valparaíso, Pontificia Universidad Católica de Valparaíso, 2014), pp. 193268. El criterio de que el carácter de canónico de una norma no viene dado por su contenido sino por la autoridad de la cual emana obedece a una construcción doctrinaria posterior. En este último punto véase Aymans, Winfried und Mörsdorf, Klaus, Kanonisches Recht. Lehrbuch aufgrund des Codex Iuris Canonici (München, Ferdinand Schoningh, 1991), p. 5.

${ }^{8}$ Atendidos los fines evangelizadores del derecho indiano se conoce al Estado indiano como Estado misional, para diferenciarlo de su coetáneo europeo, llamado confesional. Un luminoso trabajo sobre el Estado misional es Bravo LiRA, Bernardino, El Estado misional, una institución propia del derecho indiano, en Estudios en honor de Alamiro de Ávila Martel. Anales de la Universidad de Chile, $5^{\mathrm{a}}$ serie, $\mathrm{N}^{\circ} 20$ (Santiago de Chile, 1989), pp. 249-268. Texto disponible en página web www.anales.uchile.cl 
puestos: el primero de ellos es que las cláusulas de confesionalidad del Estado no restan valor al nuevo Estado constitucional' ${ }^{9}$.

El segundo supuesto es que el derecho constitucional, en base al principio de la igualdad, busca la unificación jurídica, fortaleciendo al Estado frente a las comunidades locales y otras organizaciones, cuyo derecho normalmente pierde fuerza vinculante. Dicho proceso, en el mundo hispanoparlante, hunde sus raíces en el siglo XVIII, en la política borbónica. Este proceso, denominado imperialización de la monarquía católica, significó el cuestionamiento a grupos o instituciones privilegiados, en aras del "interés general del Estado". Uno de ellos fue la Iglesia católica, tanto en lo jurisdiccional como en lo patrimonial ${ }^{10}$. De ese modo, se puede colegir que la fundación del Estado constitucional no necesariamente significó un mayor grado de autonomía para la Iglesia católica frente al Estado.

El tercer supuesto es que el derecho canónico, dentro de su unidad, reconoce una versión para Indias, que se caracterizó por contar con una elaboración científica que se hizo oponible en las Cortes. Ese derecho canónico indiano representa una adaptación de los principios y fines del derecho canónico a una realidad social y cultural distinta a la del viejo continente. Criterios unificadores del derecho en esta materia implicaban igualar al derecho canónico español con el indiano.

Una respuesta afirmativa a las interrogantes formuladas nos conduce a pensar en el derecho canónico como material susceptible de regulación en la constitución. Me atrevo a plantear esta hipótesis pues es más de una ocasión fueron los mismos diputados los que reconocieron que "la piedad religiosa es virtud, origen y fuente de las buenas costumbres y es la única precaución constitucional que puede conservarnos la libertad"11. Un sector significativo de las Cortes quería fundamentar la Constitución en la tradición, dentro de la que el catolicismo jugaba un rol fundamental.

9 En algunos países de habla hispana, dichas cláusulas fueron aparejadas de un esfuerzo por ponderar los derechos individuales con la idea de una religión oficial. En muchos casos, lo que se prohibió fue el culto público, mas quedó claro que nadie podía ser perseguido por sus convicciones. Al menos en el caso de Chile, el jurista Juan Egaña Risco, en su Memoria política sobre si conviene a Chile la libertad de culto (Santiago de Chile, Imprenta de la Independencia, 1825), diferencia entre el culto público de cualquier otro credo, prohibido, y el respeto a la libertad de conciencia y pensamiento, sagrada e inviolable. Dicha distinción fue recogida, en el caso chileno, por la Constitución liberal de 1828 , la que en sus artículos $3^{\circ}$ y $4^{\circ}$ reconoce ambas situaciones. Varios vieron ahí la introducción de la libertad de culto. Por esa razón la Constitución de 1833 fue redactada en términos más estrictos. Ello no significó desconocer esa distinción doctrinario. Sin embargo, esta no se propaló rápidamente. Muestra de ello es que tuvo que recibir sanción legal en la década de 1860 para garantizar el respeto a los mencionados aspectos de la libertad. Aparte de esto, importante es recordar que el derecho constitucional tiene una perspectiva internacional y otra de carácter nacional. En la última el constitucionalismo recogió las necesidades propias de cada país. Al contrario de Francia o Estados Unidos de América, la persecución religiosa no jugó un rol determinante ni en la formación del Estado hispano ni en la configuración cultural de esa nación. Los españoles no fueron perseguidos por su credo religioso. De ahí que un grupo importante de diputados no sintiese la necesidad de consagrar la tolerancia religiosa como principio fundamental.

${ }^{10}$ A mayor abundamiento véase Lorente, Marta y Portillo, José María (dirs.), El momento gaditano. La constitución en el orbe hispánico (1808-1826), en Colección Bicentenario de las Cortes de Cádiz (España, Congreso de Diputados, 2012).

${ }^{11}$ Diario de las sesiones de las Cortes Generales y Extraordinarias: dieron principio el 24 de 
De aceptar esta hipótesis, tendríamos que reconocer forzosamente que estamos ante un derecho que eventualmente se enfrentaba a un doble cuestionamiento, en tanto, canónico y en tanto indiano ${ }^{12}$. De esta forma la cláusula de confesionalidad era la conexión con instituciones y normas que hoy serían derecho eclesiástico o canónico, lo que va mucho más allá del laicismo o la libertad de conciencia, tan propios del constitucionalismo actual.

Las actas muestran que entre los diputados primó la idea de que los eclesiásticos debían abocarse al ejercicio de sus ministerios, siendo tarea del Estado ayudar a la Iglesia a conservar su disciplina ${ }^{13}$.

\section{Derecho canónico indiano en la obra de Justo}

\section{DONOSO}

Un análisis detallado del derecho canónico indiano excede por mucho los fines de este modesto artículo. Esperamos poder realizar dicha investigación en un futuro próximo. Eso no quita la importancia de dar una idea general acerca de cuáles eran las principales características que forjaron esa especialidad dentro del derecho canónico.

En este punto tomamos como guía la obra del obispo chileno Justo Donoso. Decidoras son las palabras proferidas por el destacado indianista Antonio Dougnac acerca de la persona y obra intelectual de este clérigo: "intelectual criollo, educado únicamente en América, con formación intelectual anclada en la época virreinal y autor de sesudos trabajos, en que, con espíritu crítico, fue examinando lo aseverado por los canonistas de diversas épocas. Su obra Instituciones de derecho canónico americano estaba llamada a darle fama imperecedera por el número de ediciones de las que fue objeto y por su irradiación en toda América hispana"14.

Tamaña referencia nos permite usar el libro mencionado por el profesor Dougnac como base para caracterizar el derecho canónico indiano, sin temor a ser poco rigurosos. Necesario es recordar que gran parte del derecho canónico indiano tiene una inspiración tridentina. El tercer concilio mexicano de 1565 y el tercer concilio limense de 1567 son una adaptación del derecho canónico indiano a lo dispuesto en Trento ${ }^{15}$. Esas normas fueron rápidamente estatizadas por la Corona. Se lo puede definir como un derecho canónico modificado por las costumbres y prácticas de la Iglesia Americana, privilegios especiales dados por la silla apostólica, concordatos, concilios americanos y leyes emanadas de la soberanía

septiembre de 1810 y terminaron el 20 de septiembre de 1813 (Madrid, García, José A. Impresor-editor, 1870), III, p. 1.714. En adelante Diario de las sesiones de las Cortes.

12 Acá citamos las palabras de Argüelles. El sostuvo que con la dictación de la Constitución de Cádiz el derecho indiano iba a ser alterado en su totalidad. Diario de sesiones de las Cortes, III, p. 1951.

${ }_{13}$ Diario de las sesiones de las Cortes, III, p. 2.182.

${ }^{14}$ Dougnac RodrígueZ, Antonio, La producción canonista italiana en dos pensadores hispanoamericanos de comienzos del siglo XIX: el chileno Justo Donoso y el peruano Francisco de Paula González Vigil, en RChHD. 24 (2013-2014), pp.17-22.

15 Dougnac Rodríguez, Antonio, Manual de historia del derecho indiano (México, Universidad Nacional Autónoma de México, 1994), p. 311. 
temporal ${ }^{16}$. Este derecho solo se hace cargo de una parte de la milenaria tradición canónica. Figuras como el prelado inferior y el abad mitrado no se conocieron en Indias. El derecho de asilo, tan extendido en Europa, en América sólo lo poseían una o dos Iglesias por pueblo. El obispo indiano es la principal figura de la Iglesia indiana. Tal importancia se debía a que era la única autoridad competente para otorgar beneficios, con la excepción del obispado y el arzobispado. Todos los oficios menores eran designados por el gobernador o el virrey, como vicepatronos, a propuesta de los obispos ${ }^{17}$. Era más poderoso que su par europeo. Tal situación se puede explicar por la ausencia de una figura eclesiástica que le sirviese de control y contrapeso. En América no hubo un nuncio apostólico. Este estaba en la corte madrileña, pero carecía de competencias respecto a la Iglesia americana. Su contrapeso y control era la burocracia indiana, en especial el virrey y la real audiencia. Tal situación tiene una explicación geográfica. La distancia respecto a la Santa Sede y la vastedad de los territorios a evangelizar demandaban la solución de problemas en base a conocimientos que la Santa Sede no tenía. De ahí que, en un acto de confianza, el Vaticano delegó paulatinamente una serie de funciones.

Las competencias jurisdiccionales del obispo eran enormes. Podía juzgar y absolver una serie de actos y casos de carácter penal que en Europa estaban reservados a la silla apostólica. Sus facultades disciplinarias abarcaban también a los regulares ${ }^{18}$. De hecho, Donoso califica la autoridad del obispo sobre los regulares como omnímoda ${ }^{19}$. En material de derecho procesal, el derecho canónico indiano disponía que todas las causas terminaran en América, apelándose la sentencia del metropolitano no al superior sino al más cercano. Las apelaciones a Roma estaban prohibidas. El derecho canónico indiano casi no tuvo relación con los tribunales romanos.

En cuanto a los concilios provinciales, entre las particularidades del derecho canónico indiano estaba la asistencia del cabildo eclesiástico en sede vacante y de los procuradores de los obispos impedidos, en ambos casos, sin derecho a voto, junto con la de virreyes y presidentes. Otra de las reglas especiales, era la de juntarse cada 12 años ${ }^{20}$.

Las normas emanadas de estas reuniones debían ser visadas por el Consejo de Indias. En lo que respecta a los sínodos de cada diócesis, en ellos participaban

${ }^{16}$ Donoso, Justo, Instituciones de derecho canónico americano escritas por el Rev. Sr. d. Justo Donoso (2a edición, Santiago de Chile, Librería de P. Yuste, 1861-1862), p. XII.

${ }_{17}$ En España esos cargos eran designados por el rey a partir de una terna presentada por el obispo.

${ }_{18} \mathrm{Al}$ ser el derecho canónico indiano un derecho cuya principal fuente de inspiración fue el concilio de Trento, este derecho canónico especial se centró en la figura del clérigo. Este, como persona consagrada a la Iglesia, debía ser un dechado de virtudes. Su vida debía ser un ejemplo y modelo para la feligresía. Como los superiores de las congregaciones no se encontraban en América, es entendible que el obispo tuviese también un control disciplinario sobre estos. Constituyó una lucha fuerte, sostenida durante el siglo XVIII, la que condujo a la primacía del obispo sobre los superiores y aun superioras de las órdenes religiosas.

19 Donoso, Justo, cit. (n. 16), p. 199.

${ }^{20}$ Esta norma no se cumplió jamás. 
el cabildo de la catedral, los párrocos y clérigos beneficiados y los regulares que servían un curato. La participación de todos ellos era consultiva.

En lo que respecta al pase regio o exequátur, la costumbre era retener aquellas decisiones que atentaban contra las regalías mayestáticas, pudiesen alterar la tranquilidad pública o que hubiesen sido dictadas con desconocimiento de la realidad. Entre las normas sujetas a trámite no se encontraban las que se referían a indulgencias, dispensas matrimoniales, dispensas de edad, oratorio y ordenaciones extratémpora.

Competencia de la Corona era la erección de nuevos obispados ${ }^{21}$. En caso de una nueva parroquia, esta medida debía contar con la autorización de la autoridad civil.

\section{REAL PATRONATO}

El real patronato existe desde antiguo en el derecho canónico ${ }^{22}$. Tan pronto como llegó Colón a América fue extrapolado al nuevo mundo. Como ya se mencionó, estatutos similares se conocieron en otras partes de la cristiandad; pero, como indica el profesor Alberto de la Hera, una de las particularidades que tendrá el real patronato indiano es que en el nuevo continente la corona controlaba la vida espiritual a vista y paciencia de la Santa Sede ${ }^{23}$.

Entre las facultades patronales indiscutidas que contemplaba ese estatuto se pueden nombrar la fundación y dotación de Iglesias, la presentación de candidatos, el cobro de los diezmos o derecho decimal, la creación de diócesis y la fijación de sus límites.

Estas facultades fueron interpretadas en las centurias posteriores de manera cada vez más extensiva, en especial en el siglo XVIII. Prueba de ello son prácticas como las cartas de ruego y encargo, el gobierno de los presentados y la aprobación regia como requisito para que los concilios entrasen en vigor, la dictación del tomo regio para la celebración de los concilios provinciales, la obligación de residencia y la restricción del derecho de asilo.

En materia patrimonial, especial importancia cobró desde la década de 1760 la tesis de Antonio Álvarez de Abreu, en virtud de la que la Corona podía disponer libremente de las rentas originadas de los beneficios vacantes, sin quedar necesariamente afectas a fines piadosos.

Gran parte de estos cambios buscaban instituir una Iglesia gobernada por los obispos en conjunto con el monarca, acorde con el ideal de disciplina y organización de la Iglesia primitiva, aquella a la que el Papa paulatinamente habría

${ }^{21}$ Atendidas las obligaciones emanadas del real patronato es entendible que la corona interviniese en la creación de una nueva diócesis. Ello implicaba construir o habilitar una catedral, nombrar un obispo y demás prebendados, determinar el territorio de la nueva diócesis, modificar el sistema de recaudo de diezmos y disponer de los fondos necesarios para cubrir todos aquellos gastos que no se alcanzaban a financiar con el diezmo.

22 De La Hera, Alberto, El regalismo borbónico en su proyección indiana (Madrid, Ediciones Rialp S.A, 1963), p. 128.

${ }_{23}$ Ibíd., p. 13. 
usurpado atribuciones. Expresión jurídica de esa interpretación histórica y jurídica fueron los recursos de fuerza y protección, cuyo fin era resguardar la disciplina intraeclesiástica y proteger a la Iglesia nacional frente a intervenciones foráneas.

El siglo XVIII fue un siglo de canonistas. Fueron ellos los encargados de fundamentar ese vínculo entre las Iglesias católicas nacionales y el monarca.

Esas posiciones dieron un paso más con las reformas iniciadas por Carlos III, quien impulsó una reinterpretación de las bulas Alejandrinas. Desde ese momento el real patronato era una manifestación del poder real, no del papal. Ese conjunto de ideas es conocido como la doctrina del poder indirecto del Estado en lo espiritual $^{24}$. De esa doctrina se deducía que "de ambas leyes, temporal y eclesiástica, se forma una república sin perjuicio alguno de las partes" ${ }^{25}$. En virtud de esa concepción, que la Corona recuperase el cobro de los diezmos no representaría ningún atropello para la Iglesia. La cesión de los diezmos siempre habría sido un acto personal, temporal y de por vida del monarca ${ }^{26}$. Esas ideas quedaron plasmadas en la redacción del Código Carolino, el que inclusive concluyó que al rey correspondía presentar a los candidatos para los empleos eclesiásticos sin decir nada acerca de los requisitos que debían cumplir los candidatos ${ }^{27}$.

No obstante, lo anterior, como en toda época, hubo movimientos en sentido contrario. El siglo XVIII vio nacer la idea de la separación completa entre la Iglesia y el Estado. Esa doctrina estaba presente en la América indiana a fines del siglo XVIII ${ }^{28}$.

\section{Discusiones constitucionales de carácter general acerca del real patronato.}

El ejercicio del real patronato ante el vacío de poder generado por la ausencia de Fernando VII suscitó una serie de debates acerca de cuál era el órgano que debía ejercer esas facultades. Como ya se vio, estas no eran pocas y abarcaban una serie de planos que rebasaban lo estrictamente religioso. Algunas de estas discusiones tocaron al patronato de manera tangencial y otras de manera directa.

Entre las primeras se puede mencionar la que verso sobre la fiscalización de la pronta administración de justicia. No estaba claro a quién correspondía en los hechos el ejercicio de esa facultad: a las Cortes o al Consejo de Regencia. Era el preludio de la introducción del principio de la división de los poderes del Estado. No estaba claro si esa atribución correspondía a las Cortes en cuanto legislativo o el Consejo de Regencia en cuanto ejecutivo. En ese orden se propuso que las Cortes nombrasen una comisión encargada de conocer los agravios de tribunales y consejos, sin distinción, lo que también abarcaba tácitamente a los tribunales eclesiásticos ${ }^{29}$.

Entre las segundas, muchas tuvieron relación con los apremios económicos producto de la guerra. No en pocas ocasiones se pensó en echar mano a los bienes

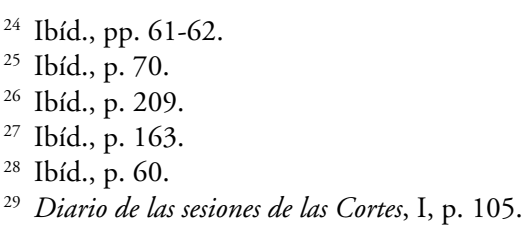


de la Iglesia en España e Indias. Las discusiones relacionadas con el real patronato siempre tuvieron dos objetivos: uno inmediato, de carácter económico, y uno de largo plazo, tendiente a adaptar a la Iglesia al nuevo orden social, fortalecer su disciplina interna y coadyuvar en un mejor ejercicio de su ministerio.

Como suele ocurrir en todas las épocas en que los sistemas jurídicos mutan, las grandes discusiones partieron de asuntos baladíes. Empezaron con una propuesta de Argüelles para economizar recursos. La idea era no proveer cargos vacantes a menos que esa provisión fuese indispensable para el culto divino. El dinero originalmente destinado al pago de esos puestos vacantes, fuesen curatos o prebendas en las iglesias catedrales, sería destinado a financiar los costos de la guerra $^{30}$. La misma suerte correrían los diezmos pertenecientes a cabildos y comunidades religiosas ${ }^{31}$. Argüelles sostenía una postura regalista propia del siglo XVIII. Para él no era necesaria la anuencia de la Santa Sede a la hora de suprimir prebendas o cargos eclesiásticos. Consideraba que tales facultades eran inherentes a la soberanía. Cuatro días después esa propuesta fue puesta en tabla. El diputado Cañedo se opuso, por considerar que esa medida atentaba contra las facultades de la Iglesia y el Papa. La discusión se trató de zanjar suspendiendo la provisión de cargos en España y América mientras una comisión se encargaba de estudiar el alcance de las bulas que otorgaron ese derecho al rey ${ }^{32}$. El trabajo de la comisión, al parecer, no se realizó con la premura esperada, ya que en la sesión del 7 de diciembre de 1810, se volvió a proponer una exacción especial para todos los que trabajaban en el aparato estatal o recibían su sueldo de cargo de la Corona. Dicho impuesto gravaba también a obispos, cabildos eclesiásticos, párrocos, dignidades y comendados de órdenes regulares, contemplando además que se requisase una prebenda, a elección del eclesiástico afectado, cuando este percibiese más de una ${ }^{33}$.

Si bien esa propuesta no fue admitida a discusión, da cuenta del interés de los diputados en disponer de parte de los bienes de la Iglesia en momentos de apuro económico.

Mes y medio después fue presentada una tercera propuesta en la misma dirección. A diferencia de las anteriores, esta buscaba introducir modificaciones de fondo en la administración de la Iglesia indiana, partiendo de la base que la repartición del diezmo permitía vivir dignamente a todos los miembros de la Iglesia. Este se dividía en cuatro partes, quedando una para los obispos, otra para los cabildos eclesiásticos ${ }^{34}$ y de la otra mitad se hacían nueve partes, novena y medio para la construcción de nuevas iglesias, novena y medio para hospitales, dos novenos para el monarca y los otros cuatro novenos, llamados beneficiales en el tercer concilio mexicano ${ }^{35}$, estaban destinados al pago de curas y ministros con

${ }^{30}$ Ibíd., I, p. 129.

31 Ibíd.

32 Ibíd., I, p. 138.

33 Ibíd., I, pp. 149-150.

34 Obispos y cabildos eclesiásticos se llevaban la parte del león.

35 El tercer concilio mexicano tuvo un marcado acento en la educación del indígena, a fin que comprendiese la importancia de cada sacramento y la necesidad de su administración. Véase 
ocasión de la administración de los sacramentos ${ }^{36}$. Al estar todos bien remunerados, la falta de dinero no sería excusa para no administrar los sacramentos. Sin ellos no se podía alcanzar la vida eternal.

En los hechos, las constituciones conciliares tocantes a los beneficiales habían caído en desuso. La labor evangelizadora demandaba mucho y el monto a repartir por concepto de beneficiales era magro. Por consiguiente, se autorizaron los aranceles, cobros que se efectuaban por la administración de los sacramentos. En aras de una optimización de los recursos, el representante por Querétaro, diputado Mariano Mendiola Velarde, propuso volver al sistema original, ya que el monto de los diezmos en ese momento sí permitía a los párrocos y sacerdotes vivir dignamente y administrar los sacramentos sin necesidad de esperar una retribución de los feligreses. Esta propuesta fue acogida favorablemente, a tal punto que el diputado por Valencia Joaquín Lorenzo Villanueva pidió extenderla a España. La administración de los sacramentos siempre debía ser gratuita como "consecuencia del espiritu de la Iglesia en todos los siglos, como lo demostraban los sagrados cánones" ${ }^{37}$.

Una segunda discusión de carácter general tuvo lugar por la dictación del reglamento provisorio del Consejo de Regencia. En los hechos se trataba de la introducción del principio de separación de los poderes del Estado, ya no como práctica o precedente sino como norma escrita. El Consejo de Regencia, como órgano ejecutivo, era el competente para nombrar a los empleados eclesiásticos. La propuesta, abiertamente regalista, encontró resistencias en el pleno. Así el diputado Espiga sostuvo que esa norma contradecía el derecho canónico, pues iba más allá del derecho de presentación. Dicho diputado indicó además qué casos quedaban dentro del real patronato ${ }^{38}$.

Si bien se acordó que se hablase de presentación, se concordó que las Cortes, por la circunstancia de detentar la soberanía, tenían derecho a intervenir en el nombramiento de los empleos eclesiásticos. El fundamento fueron los concilios de Toledo y el hecho de la "gran influencia que tiene la dignidad de un arzobispo y de un obispo en toda la nación y mucho más respecto a América [...] Ninguna diligencia será sobrada para asegurarse de las circunstancias y calidades de una persona de tanta influencia. Quien haya estado en aquellos paises conocerá que no hay ejército, por numeroso que sea, que tenga tanta fuerza e influjo como los obispos, y esta será tanto mayor, cuanto sea su dignidad, su literatura y sus costumbres" 39 .

Mención especial merece la discusión acerca del préstamo de la plata labrada de las iglesias y particulares. En la práctica era un préstamo forzoso, una exacción cuyo resarcimiento quedaba sujeto a los albures propios de la guerra. De ahí que esta medida provocase tanta resistencia. Como los recursos eran escasos, pronto se habló de hacerla extensiva a América, en aras de la igualdad en la repartición

Cruz Barney, Oscar, Historia del derecho en México (2a edición, Ciudad de México, Oxford University Press, 2010), p. 584.

36 Diario de las sesiones de las Cortes, I. p. 406.

37 Ibíd.

38 Ibíd., I, p. 205.

39 Ibíd., I, p. 206. 
de las cargas públicas ${ }^{40}$. Más de algún diputado americano presto su asentimiento, en aras del nuevo trato social que se estaba celebrando en las Cortes ${ }^{41}$.

Sin embargo, la mayoría fue de la idea contraria. Pidió que tuviese un carácter extraordinario, que gravase primero a los particulares y en último caso a las Iglesias, excluyendo de ellas a las parroquias y a las iglesias de indios ${ }^{42}$.

José Miguel Guridi y Alcocer, diputado por Tlaxcala, hizo público su disenso. Sus argumentos reflejaron realismo político puro y duro: más impuestos tras el gobierno de Carlos IV solo contribuirían a atizar el descontento. Dicha exacción se podría interpretar como una amenaza a la Iglesia en su conjunto. El proyecto constitucional era aún débil. No podía permitirse perder apoyo social. Por esos motivos, Guridi propuso recaudar fondos por vía de donaciones ${ }^{43}$. En la misma dirección, aunque con argumentos más jurídicos, intervino el diputado Simón López. Hizo presente que tales normas iban contra "las leyes divinas y humanas". En caso de llevarse a cabo esta medida, se debería pedir la anuencia de los obispos, "acorde lo prescrito en los sagrados cánones y en los concilios" ${ }^{4}$. Al día siguiente, el diputado por Guadalajara José Simón Uria y Berruec continuó desarrollando la postura de Guridi y López. La guerra en América estaba desatada. Los saqueos y la sensación de que la religión estaba amenazada no hacían aconsejable la medida. Uria también se mostró partidario de recaudar fondos por vía de donación, recordándole al pleno que solo la iglesia de Guadalajara había efectuado donaciones ascendientes a $\$ 600.000$ fuertes ${ }^{45}$. Vicente Morales Duarez, como diputado por Perú, también hizo alarde de la generosidad del clero peruano, fuese este secular o regular, siendo la mejor prueba la ayuda económica que, vía donaciones, hicieron llegar al virreinato de la Plata y a la ciudad de Buenos Aires a causa de la invasión inglesa. Para Morales no era misterio que dicha medida deslegitimaría al proyecto constitucional gaditano y que los sectores populares, el campesinado y el indígena percibirían tal medida como abuso, opresión y amenaza ${ }^{46}$. "Ignorando la novella de Justiniano como las otras sanciones legales que licencian los casos en que es permitida la distracción o enajenación de las cosas de la Iglesia y no habiendo visto jamás práctica de su uso, reputan esos bienes como exclusivos de la divinidad, a donde no puede introducir mano ninguna autoridad humana" ${ }^{47}$. En último caso, Morales pidió eximir de este pago a las parroquias.

Tras la intervención del obispo prior de León hubo consenso en que no era aconsejable aplicar esa medida en Iglesias situadas en poblaciones indígenas. El sugirió concientizar a los obispos, cabildos y prelados para que ellos asumiesen el recaudo de las donaciones.

${ }^{40}$ En los debates se menciona el lujo de la catedral de Querétaro y del Santuario de Nuestra Señora de Guadalupe, así como de los 40 conventos de monjas dotados de grandes alhajas que había en México.

${ }^{41}$ Diario de las Sesiones de las Cortes, II, pp. 840-841.

42 Ibíd., II, p. 842.

43 Ibíd.

44 Ibíd.

45 Ibíd., II, p. 844.

46 Ibíd.

47 Ibíd. 
Dicha postura recibió el apoyo del diputado por Perú Blas Ostolaza y del representante por Valladolid, Nueva España, José Cayetano Foncerrada y Ulibarri. Todos reconocieron el alto grado de legitimidad social y las enormes facultades del obispado indiano. Sin su apoyo, ninguna medida de ese tipo podía producir efectos $^{48}$.

En lo jurídico, todos citaron las novelas de Justiniano, el código teodosiano y las capitulares de Carlo Magno. También se citaron prohibiciones para los príncipes consagrados en el III concilio Lateranense. La única posibilidad para lograr disponer de esos medios era encargando una gestión conjunta del cabildo eclesiástico y el obispo. Al final, la norma se aprobó, con la excepción de las iglesias de indios y de las parroquias, quedando la implementación de esa norma en manos de una comisión de eclesiásticos ${ }^{49}$.

\section{Prebendas.}

Pese a ser un tema muy relevante en aras de un nuevo trato entre americanos y peninsulares, una discusión sistemática al respecto del rol pastoral y evangelizador del Estado no estuvo en la agenda de las Cortes sino después de un año de entrar en funciones. Fueron los hechos los que obligaron a las Cortes a pronunciarse. La solicitud del arcediano de la catedral metropolitana de Santa Fe de Bogotá de que, pese a la suspensión de toda provisión de nuevas prebendas, se le concediese una en razón de sus méritos llevó a plantear cuál era la situación de estas en la Iglesia indiana $^{50}$. Si bien las Cortes valoraron el servicio que el solicitante había prestado a la monarquía, hubo cautela en cuanto al precedente que se podría generar. Ante ese escepticismo, propio de un momento de convulsión política, agregó el diputado Morales Duarez que la costumbre y la práctica habitual en el derecho indiano era que los miembros del cabildo eclesiástico fuesen los que gozasen de la prioridad a la hora de adjudicar prebendas catedralicias. El diputado catalán José Espiga y Gadea rebatió a Morales. Reconoció la existencia de esa costumbre canónica; pero estimó que esa solicitud daba a las Cortes la posibilidad de reformas la composición de los cabildos y aumentar el número de plazas destinadas al culto. En su opinión, la existencia de seis u ocho canónigos no bastaba para cumplir con las labores pastorales ${ }^{51}$. Para ello hizo mención a que en la Nueva España solo 4 Iglesias contaban con 25 canónigos. El diputado por Tarragona, Ramón de Utges, participó de este debate, cuestionando la juridicidad de las prácticas aludidas por Morales Duarez, pues en América no se observaría una rigurosa promoción dentro de la carrera eclesiástica.

Tales argumentos, junto a la solicitud de informes acerca del estado de la Iglesia al Consejo de Indias, dejaron esta solicitud pendiente de resolución hasta contar con mayores antecedentes ${ }^{52}$.

Dicho informe desaprobó la política de suspender la otorgación de prebendas,

\footnotetext{
48 Ibíd., II, pp. 846-847.

${ }^{49}$ Ibíd., II, p. 849.

50 Ibíd., I, p. 697.

51 Ibíd., I, pp. 697-698.

52 Ibíd., I, p. 698.
} 
por ser su número ya muy corto. Al ser su fin era la evangelización, esa vacancia perjudicaría el culto ${ }^{53}$.

El Consejo fundamentó sus aseveraciones en que entre iglesias metropolitanas, catedrales y colegiatas en todas las Indias sumaban 47 . De ellas solo cinco tenían una planta de 26 prebendas, 17 entre 10 y 19, 20 de 2 a 9, mientras Nueva Segovia, Nueva Cáceres, Sonora, Cebú y Mainas no poseían prebenda alguna asignada ${ }^{54}$.

El Consejo propuso que los criterios para proveer prebendas fuesen: mérito y que en igualdad de méritos se prefiriese a los curas párrocos y doctores residentes en América ${ }^{55}$. Villanueva asintió en la propuesta, por ajustarse al derecho canónico, solicitando que por ley se prohibiese la práctica, arraigada en Indias, de adjudicar las prebendas a los clérigos de las catedrales, optando en su lugar por catedráticos, párrocos y eclesiásticos destacados por su virtud y sabiduría.

No faltaron los diputados peninsulares que se opusieron a esta medida en razón de la igualdad. Se perjudicaba a los peninsulares. Ellos fueron rebatidos por el representante del virreinato del Perú, Dionisio Inca Yupanqui, quien cerró la sesión protestando por la desigualdad existente en el número de prebendas para España e Indias.

La propuesta del Consejo de Indias generó controversia. El diputado por la ciudad de México José Ignacio Beye de Cisneros la consideraba inútil por repetitiva e ilusoria ${ }^{56}$. La lista de providencias dictadas en ese sentido era muy larga y ninguna de ellas se había cumplido. En los hechos el único criterio para su otorgamiento era el arbitrio y componendas motivadas por intereses mezquinos. Propuso la equidad natural, como criterio orientador "madre de todas las leyes" 57 , o en subsidio que se adjudicase la mitad de las prebendas a los naturales de la diócesis respectiva y la otra mitad a europeos y americanos de otras diócesis. Para ello argumentó que el privilegio de nacimiento era propio del derecho canónico, de las Partidas y del derecho indiano en Rec. Ind. 2, 22, 4. El problema es que dicho criterio nunca había sido seguido ${ }^{58}$.

Ese motivo, unido a la declaración de igualdad hecha por las Cortes, llevó al diputado por Durango Juan José Guerena a proponer que el único criterio fuese el mérito y que toda vacante en Europa o América, fuese provista indistintamente en peninsulares o americanos ${ }^{59}$.

Tal propuesta se rechazó en razón de lo reducido del clero indiano y, sobre todo, por no ser garantía de una mejor evangelización. Los oriundos de una región eran mejores conocedores del dialecto indígena, de las costumbres y necesidades

53 Ibíd., II, p. 856.

${ }^{54}$ Ibíd. El citado informe agregaba que las seis iglesias de mayor número en Indias (México, Tlaxcala, Valladolid, Guadalajara, Lima y Charcas) reunían 149 prebendas frente a las 596 de las seis iglesias más grandes de España (Toledo, Sigüenza, Sevilla, Santiago, Palencia y Zaragoza). En Indias en total había 501 prebendas frente a 4.103 de España.

55 Diario de las sesiones de las Cortes, II, p. 857.

56 Ibíd., II, p. 859.

57 Ibíd.

58 Según Cisneros en el obispado metropolitano de México de 29 arzobispos solo uno había nacido en Nueva España y en Puebla, de los 21 prelados, solo 3 eran oriundos de ese virreinato.

59 Diario de las Sesiones de las Cortes, II, p. 860. 
locales. Por ende, estaban en mejores condiciones de identificarse con la grey. Además, esa propuesta iba contra lo prescrito por los concilios. Estas normas contenían un orden de prelación: los hijos de los conquistadores, luego los pobladores y por último los naturales ${ }^{60}$. Dicho criterio fue reproducido por la comisión eclesiástica de las Cortes. Sin embargo, la dictación de esa resolución contó con dos votos disidentes. Uno correspondió al diputado Cañedo, que se opuso a un estatuto preferente para los americanos pues constituía un acto de discriminación positiva, atentaba contra la evangelización y la igualdad de derechos los españoles americanos y peninsulares. Sostuvo que la religión debía ser el elemento de unidad de la nación española por antonomasia. La formación de cleros de carácter nacional no coadyuvaba a aquellos fines ${ }^{61}$. El otro voto particular correspondió al diputado Blas Ostolaza. El también opinó que ese dictamen y el informe del Consejo eran nuevos de puro viejos. El criterio de preferir a los naturales de la provincia o reino en que se encuentran las plazas a adjudicar venía desde la época de los padres de la Iglesia, lo que fue recogido por Part. 1, 3, $15^{62}$ y posteriormente reiterado por los reyes católicos, al erigir el obispado de la isla Española. Dicha disposición fue recepcionada posteriormente por las cédulas que erigieron las restantes iglesias indianas. El diputado peruano indicó que esa norma era transgredida pues cada nuevo obispo llegaba con un séquito de personas de su absoluta confianza. Por eso, Ostalaza solicitó que las prebendas en indias solo se adjudicasen a los nacidos en ellas ${ }^{63}$. Al cabo de unas semanas toda esta discusión volvió a foja cero, pues la medida que la motivó, la suspensión del otorgamiento de las plazas vacantes, quedó sin efecto por resolución de las mismas Cortes ${ }^{64}$. Esa decisión fue interpretada como un privilegio. Obispos españoles pedirían meses más tarde que se concediese a sus diócesis el privilegio de proveer las prebendas vacantes ${ }^{65}$.

El tema no quedó cerrado con esa decisión. Varios canónigos destinados al servicio de catedrales en América no viajaron a sus sedes, infringiendo la obligación de residir en sus diócesis ${ }^{66}$. Se menciona el caso de Agustín de los Arcos, quien no quería viajar a México, completando seis meses de vacancia. Dio la excusa de los americanos volver a pedir la exclusividad ${ }^{67}$.

Casos similares motivaron reformas en el sistema de rentas. La oportunidad la dio el obispo de Valladolid de Michoacán, Manuel Abad y Queipo, quien solicitó se le pagase la renta desde la toma de posesión del obispado. El Consejo de Indias estimó que se debía pagar el sueldo desde que se entraba a poseer los puestos, con cargo a las cuartas episcopales vacantes. Se acordó que el monto destinado a ese fin fuese la mitad, si los ingresos de la iglesia superasen los $\$ 35.000$ y de dos

\footnotetext{
${ }^{60}$ Ibíd., II, p. 861.

61 Ibíd.

${ }^{62}$ La referencia dada no corresponde con el contenido de la norma.

${ }^{63}$ Diario de las sesiones de las Cortes, II, p. 862.

${ }^{64}$ Ibíd., II, p. 879.

65 Ibíd., III, p. 1.783.

${ }^{66}$ Ibíd., II, p. 1.070.

67 Ibíd.
} 
tercios si estos oscilaban entre $\$ 35.000$ y $\$ 25.000$ y de tres quintos si no pasaban de los $\$ 15.000^{68}$.

Meses después este tema volvió al foro, esta vez por la impugnación de la designación del arcediano de la catedral de Puerto Rico. Dicha impugnación fue presentada por el cabildo de esa catedral, solicitando que ese cargo fuese adjudicado al racionero o al miembro más antiguo de ese cabildo, dejando sin efecto el nombramiento hecho por el Consejo de Regencia en la persona de Miguel Armida, párroco de la isla de León ${ }^{69}$.

Esta impugnación levantó una polvareda entre diputados españoles y americanos. Los primeros alegaron que, previo al informe del Consejo de Indias ${ }^{70}$, se determinó que no había norma que estableciese una escala o criterios de preferencia entre los postulantes $\mathrm{y}$, por ende, un reconocimiento de sus méritos, como se habría dado en el caso de Armida ${ }^{71}$. Agregaron que la usanza del real patronato respecto a las vacantes catedralicias era de la más absoluta libertad de decisión. El diputado Ostaloza planteó el carácter errado de esa tesis. Se apoyó en las decisiones de los reyes católicos y en las leyes de indias, que mandaban se otorgasen las prebendas a personas nacidas en esas provincias. Morales Duarez agregó que si bien las leyes escritas no eran del todo claras, existía el "derecho de los naturales" recogido por el derecho canónico a través de los concilios, resoluciones pontificias y sínodos y por el testamento de Isabel la Católica, que a su vez disponía que se prefiriese a los hijos de los conquistadores, cuya voluntad había sido, según Solorzano, recogida por sus sucesores ${ }^{72}$.

Varios diputados acogieron la juridicidad de estos argumentos, pero plantearon que el acto jurídico ya era perfecto y por lo tanto producía efectos, por lo que no correspondía revocarlo ${ }^{73}$.

La discusión finalizó acordando que el único criterio para el ascenso en la carrera debía ser el mérito, fuese esta militar, eclesiástica, togada o en la planta de la administración pública ${ }^{74}$. Sin embargo, esta determinación cayó a los pocos días en el baúl de los recuerdos. El 4 de agosto de 1811 la comisión de premios de las Cortes propuso recompensar a los defensores de Zaragoza con prebendas y empleos civiles en América ${ }^{75}$. Indias era un premio para los que combatían en España.

Finalmente, cuando se discutieron las facultades del monarca constitucional, se ratificó el real patronato, al ser competente para presentar a los clérigos para obispados, dignidades y beneficios eclesiásticos, a propuesta del Consejo de Esta-

${ }^{68}$ Ibíd., II, pp. 1.185-1.186.

${ }^{69}$ Ibíd., II, p. 1.593.

${ }^{70} \mathrm{~A}$ la Cámara de Indias tanto las Cortes como el Consejo de Regencia le consultaban todo lo relativo a empleos en la judicatura y prebendas eclesiásticas, real patronato y reales cédulas. Eso hizo que el Ministerio de Gracia y Justicia decidiese permanecer en Cádiz, cerca de la sede del consejo, en lugar de trasladarse a Murcia.

${ }^{71}$ Diario de las sesiones de las Cortes, II, p. 1.561.

72 Ibíd., II, p. 1.594.

${ }^{73}$ Ibíd., II, p. 1.595.

${ }^{74}$ Ibíd.

${ }^{75}$ Ibíd., III, p. 1.648. 
$\mathrm{do}^{76}$. En ese momento se volvieron a discutir las diferencias entre Indias y España. La solución propuesta por Argüelles y Gutiérrez de la Huerta fue que la mención al Consejo de Estado dejaba intactas las facultades de obispos y reyes, siendo su posterior pormenorización material del reglamento del Consejo de Estado ${ }^{77}$. No se quiso discutir una reforma a las facultades de los obispos ${ }^{78}$.

\section{Pago de congruas a los doctrineros en Perú.}

La mantención de estos sacerdotes no fue una preocupación ajena a las Cortes. Dichos sacerdotes son una de las instituciones más representativas del Estado misional indiano ${ }^{79}$. Sucesivas normas reiteraban la obligación jurídica del Estado de pagar la congrua a los sacerdotes responsables de la población aborigen, existiendo un mandato jurídico para la Corona de cubrir aquella suma pendiente de pago después de la liquidación del diezmo. Si bien en diversas regiones de América había curas de indios, problemas con el pago de su congrua -que motivaran una discusión en la Corte- hubo solo en Perú. Esto se debió a que esos sacerdotes eran mantenidos con cargo a tributos que los indios pagaban, sin tener aquellos la costumbre de pagar una cantidad anual al sacerdote por su labor. Por eso, la abolición de ese tributo dejó a los curas de indios sin sustento, generándose una discusión acerca de cómo se debía garantizar su manutención. El diputado Blas Ostolaza propuso que desde ese momento esos sacerdotes fuesen remunerados con la porción del diezmo que le correspondía al monarca por expresa donación pontificia y si esta no alcanzaba, con cargo a la cuota que le correspondía al obispo $^{80}$. La comisión ultramarina acogió esta propuesta. Primero con cargo a la porción real del diezmo, luego a la caja de la comunidad indígena y, por último, el saldo restante debía ser pagado por la Real Hacienda ${ }^{81}$.

Esta propuesta fue objeto de debate. El diputado Inca planteó que por el hecho de ser desde ese momento el diezmo obligatorio para los indígenas, su masa se acrecentaría y con ella bastaría para pagar las congruas, aunque tal situación no sucedería sino antes de dos o tres años. Ese diputado hizo presente que gran

76 Ibíd., III, p. 2.084.

77 Ibíd., III, p. 2.085.

${ }^{78}$ El Consejo de Estado, órgano típico de la monarquía, fue visto como una reacción frente al autoritarismo borbónico. Lo que lo diferenciaba de los consejos de la dinastía Habsburgo era que este tendría una labor gubernativa, no consultiva. Por esa razón, la integración de éste por eclesiásticos fue vista como una garantía de un mejor gobierno y de mejores relaciones con el poder espiritual.

79 Aunque el profesor Bravo Lira no los menciona expresamente en su trabajo arriba citado, los doctrineros o curas de indios se corresponden perfectamente con todos los principios que sustentaban al Estado misional. Son uno de los mejores ejemplos de una organización estatal donde el poder temporal y el espiritual están entrelazados. Los clérigos, sacerdotes y misioneros necesitaban apoyo intelectual y material para poder cumplir con su labor evangelizadora. Ellos no esperan que los aborígenes vayan a la Iglesia o a la ciudad que servía de asiento a la catedral. Ellos salían a buscar al indígena a su comunidad y/o lugar de trabajo. Esa labor debía ser remunerada. Bravo LiRa, Bernardino, cit. (n. 8).

${ }^{80}$ Diario de las sesiones de las Cortes, II, p. 910.

${ }^{81}$ Ibíd., II, p. 1.288. 
parte del diezmo quedaba en manos de los obispos y cabildos eclesiásticos ${ }^{82}$. Los párrocos no percibían per se porción alguna del diezmo, pero cada uno de ellos tenía asignada una cuota, llamada sínodos, citando para estos efectos Rec. Ind. 1, 23, 21; 1, 6, 1 y 2, 2, 8, junto con la bula Eximiae devotionis de Alejandro VI, datada el 15 de noviembre de $1501^{83}$.

Inca propuso su pago con cargo al diezmo, luego con la parte que le correspondía al rey en los novenos y por último por la Hacienda Real (Rec. Ind. 1, 23, 21 y $2,2,13)$. Para fiscalizar su cumplimiento planteó que cada virreinato y capitanía general contase con una comisión encargada de la administración del diezmo, en la que estarían el virrey, el obispo o arzobispo, el regente, el intendente, el fiscal, el protector de naturales y el cura más antiguo de la catedral.

A varios les pareció un proyecto interesante; pero toparon con el hecho que las soluciones propuestas por la comisión ultramarina podían colisionar con lo propuesto por la comisión de hacienda, que pretendía gravar la cuarta que percibían las iglesias catedrales con el pago a los curas en general. ${ }^{84}$

Así surgió la idea, expuesta por el diputado Mendiola, de pagar a los curas de indios con los novenos y no con cargo a la caja de comunidad ${ }^{85}$. Era partidario de aplicar la normativa de los diezmos de acuerdo a su sentido original. Rechazó la costumbre contra ley. En este caso, los 4/9 estaban destinados al sustento de los clérigos en general, olvidando que esa porción de la masa decimal estaba dirigida a la administración de los sacramentos. Mendiola fundamentó esa postura en la letra de las constituciones del III Concilio mexicano, y en su aprobación tanto por la Santa Sede como por la Corona ${ }^{86}$.

Una dosis de realismo agregó el diputado Morales Duarez. El recalcó que la situación de los curas de indios era una particularidad de la Iglesia peruana, debida al pastor Santo Toribio de Mongrovejo, a fin de que la evangelización se realizase acorde la cultura de los aborígenes ${ }^{87}$. El doctrinero contaba con el apoyo de un "interés", en razón de las dificultades geográficas de cada zona. Subrayó que el doctrinero y su "interés” llegaban a lugares dónde ni el subdelegado ni el jefe de partido jamás habían llegado. De ahí su enorme relevancia política para la monarquía. Poseían una influencia mayor en sus comunidades a aquella que tenía la burocracia indiana. Morales los califica como similares " a los antiguos curacas" Por todo eso, de una pronta solución dependía la estabilidad política del Perú ${ }^{89}$.

82 Ibíd., II, p. 1.289.

${ }^{83}$ Ibíd. Esa intervención confundió el pago del diezmo con el de otras donaciones y la mayor o menor opulencia de las parroquias con la cantidad percibida.

${ }^{84}$ Importante es destacar que en la división del diezmo la discusión se remite al III concilio mexicano, pese a tratarse de un problema que aquejaba a la Iglesia peruana, regida por los concilios limenses.

${ }^{85}$ Diario de las sesiones de las Cortes, II, p. 1.290.

86 Ibíd.

87 Ibíd.

88 Ibíd., Tomo II, p. 1.291.

89 Ibíd. 
El fundamento legal, aparte de las citadas normas, lo encuentra en las ordenanzas de intendentes, y en los artículos 150 y 166 del Código Carolino de $1782^{90}$.

Morales hizo presente que solo la caja de indios de Lima tenía excedentes. Estos eran invertidos en mandar a un grupo de jóvenes al Colegio del Príncipe ${ }^{91}$. Tampoco veía viable el pago con cargo a los 4/9 destinados a la administración de los sacramentos pues la agricultura peruana reclamaba una serie de reformas para poder acrecentar el monto de los diezmos. Señaló además que en Perú no había costumbre de que cada persona ofreciese un real por misa prestada, como si existía en México, llamado Miratomin. Él explicó estas diferencias con las siguientes palabras: "Entiéndase, para ahora y en adelante, que los reinos de América son tan varios en sus posiciones como en sus climas, frutos, usanzas, virtudes y vicios, exigiendo variedad de reglamentos como lo evidencian la Recopilación, ordenanzas de intendentes y minería, muchas cédulas y reglamentos particulare" $" 92$. Por ese motivo, Morales rechazó las propuestas del diputado Inca. Él había abandonado tempranamente Perú, y la de Mendiola, por corresponder a la realidad novohispana. Al final la propuesta se aprobó tal como salió de la comisión ultramarina ${ }^{93}$.

Dicha decisión generó un conflicto de competencia con el Ministerio de Hacienda en Indias. Un mes más tarde esa repartición hizo llegar sus objeciones. Celosos del resguardo de las finanzas públicas, objetaron la interpretación jurídica predominante acerca de la obligación de hacienda de pagar la congrua a los doctrineros, pues los novenos reales del diezmo obligaban a la Corona cuando esta hacia suyos todos los diezmos, pues en ese caso era responsable de su cobro. No era lo que ocurría en el Perú, donde el órgano responsable del cobro era el cabildo eclesiástico $^{94}$. La Real Hacienda tampoco podía entender que los virreinatos de La Plata y Santa Fe no hubiesen elevado peticiones similares, siendo que en esos territorios también había curas de indios ${ }^{95}$. Finalmente negó a tales pagos mientras la Iglesia administrase los diezmos ${ }^{96}$. Ínterin, el pago de esa congrua sería de cargo de los obispados ${ }^{97}$.

Recién en febrero de 1812 se pudieron uniformar los criterios entre los órganos competentes. La comisión ultramarina, después de escuchar los requerimientos de todos los órganos injerentes, reconoció la importancia de los doctrineros para el orden social en América, y la estrechez por la que atravesaba el erario peruano, asintiendo en que eso no era excusa para cumplir con lo dispuesto en los diversos cuerpos legales vigentes en Indias. Sin embargo, manifestó la importancia de distinguir en qué medida estaba la Corona obligada y en qué medida lo estaba la Iglesia. Su postura fue que la primera solo estaba obligada en la medida en que cobraba, administraba y se hacía dueña del diezmo. Eso no pasaba en Perú, don-

\footnotetext{
90 Ibíd.

91 Ibíd.

92 Ibíd., II, p. 1.292.

93 Ibíd., II, p. 1.294.

${ }^{94}$ Ibíd., II, p. 1.474.

95 Ibíd.

${ }^{96}$ Ibíd., II, p. 1.475.

97 Ibíd.
} 
de la corona lo había cedido a obispos y cabildos eclesiásticos ${ }^{98}$. Su fundamento legal fue el artículo 150 de la Ordenanza de Intendentes, que prescribía que los diezmos pertenecían al ramo de Hacienda, cuya administración y cobranza recaían en una junta, en que si bien había sacerdotes, ellos ejercían jurisdicción real. Con una visión muy dieciochesca y regalista, se sostuvo que el diezmo era parte de la soberanía real. Era el monarca el que lo había cedido de manera graciosa ${ }^{99}$.

Luego indicó que era urgente fijar un tributo de carácter supletorio. Con ello la comisión ratificó su propuesta inicial, pero al acoger los criterios emanados de hacienda dejó el tema abierto. Se remarcó que el fin del diezmo era la propagación de la fe y que este era originariamente una atribución de la Corona. Un punto nuevo lo agregó Argüelles, quien se opuso a establecer un nuevo impuesto. En su lugar, el propuso gravar con ese pago a los cabildos eclesiásticos más ricos del Perú ${ }^{100}$.

Sobre el diezmo, se agregó que en Perú, entre los indios, su pago se mezclaba con el de otros impuestos, habiendo perdido su individualidad, en cuanto a institución ${ }^{101}$. Luego de una larga discusión acerca de su naturaleza y de lo prescrito por la legislación vigente, en especial por las citadas Ordenanzas, se acordó ceñirse a lo prescrito por la Regencia ${ }^{102}$; es decir, lo mismo que propuso la comisión ultramarina.

Esta discusión muestra dos aspectos que caracterizaron a las Cortes a la hora de discutir la realidad Indiana: si bien existía conciencia acerca de las peculiaridades y diferencias respecto a España, el cúmulo de tareas que demandaba sentar las bases de un nuevo orden social no permitió que los diputados entendiesen a cabalidad qué medidas eran realmente importantes. Descuidar el pago de los doctrineros era minar las bases de la monarquía y la nación española del otro lado del Atlántico. Por momentos parecía que se renunciaba a la bendición por un plato de lentejas. Nadie estaba mejor calificado para ser ministro de fe en material civil o electoral que el párroco ${ }^{103}$.

El segundo aspecto es la permanente reivindicación de la especialidad del derecho indiano frente al hispano, tanto a nivel continental como local, lo que dificultaba cualquier intento unificador y uniformador, tendiente a formar un derecho común a todo el imperio.

98 En América efectivamente se dieron casos en los que la Corona volvió a donar los diezmos a la Iglesia, reservándose solo una parte. En esos casos se entendía que la Corona podía ejercer labores de control en razón del real patronato, de la protección de sus regalías y del interés de hacienda. Por lo demás, como ya se dijo, en el siglo XVIII se entendió que esa donación era revocable. Véase DE la Hera, Alberto, cit. (n. 22), p. 152.

99 Diario de las sesiones de las Cortes, IV, p. 2.769.

${ }^{100}$ Ibíd., IV, p. 2.773.

101 Ibíd., IV, p. 2.779.

102 Ibíd., IV, p. 2.782.

103 Con mayor realismo que en el pago de las congruas, la organización electoral se realizó en base a las parroquias. El párroco era el idóneo para verificar la edad, y la residencia de un elector en los libros de bautismo. Además, nadie conocía mejor la realidad de los aborígenes que vivían en los pueblos de indios. 


\section{Obispados.}

En marzo de 1812 se acordó fundar el obispado de El Salvador, sufragáneo del de Guatemala. José Ignacio Ávila, diputado por el Salvador, presentó esta solicitud por encargo de su provincia, pidiendo que la silla episcopal tuviese asiento en esa ciudad. Fundamentó su petición en la extensión del reino de Guatemala, el volumen de los diezmos percibidos en ese territorio y en que la población total de ese arzobispado ascendía a más de 600.000 personas. Solo San Salvador tenía más de 180.000 habitantes. La labor evangelizadora reclamaba un nuevo obispado. La Corte, en calidad de detentadora de la soberanía, ejerció las atribuciones que a ese respecto contemplaba el derecho canónico indiano, remitiendo el acuerdo de fundación a la Regencia para su implementación ${ }^{104}$.

\section{Exequátur.}

Si bien esta institución tuvo alcances muy distintos a ambos lados del Atlántico, merece ser mencionada. El exequátur entró al ruedo recién al momento de discutirse las facultades del Supremo Tribunal de Justicia, en particular con ocasión de algunas modificaciones propuestas por el diputado valenciano Josén Antonio Sombiela ${ }^{105}$.

Propuso que ese tribunal "conociera de todos los recursos de fuerza de las causas tocantes al santo concilio de Trento, [...] todas las bulas, breves y rescriptos apostólicos para el plácido o exequátur región y conocerá de todos los recursos sobre retención y suspensión de las citadas bulas y letras apostólicas" ${ }^{106}$. La comisión redactora del proyecto de constitución estimó que el primer caso era competencia del monarca y de las Cortes; el segundo del rey, previa consulta al Consejo de Estado y el tercero, de volverse contencioso, del tribunal. La comisión interpretó el exequátur desde una perspectiva regalista ${ }^{107}$. En España abarcaba bulas, breves, gracias, perdones, indulgencias y jubileos ${ }^{108}$. El derecho español sistematizó las bulas y breves acorde a su contenido. Este determinaba a qué examen de juridicidad eran sometidas. Así, aquellas de carácter general, las que afectaban las regalías del rey o las que contravinieran el concilio de Trento eran sometidas a revisión ${ }^{109}$. Se exceptuaban las que versaban sobre dispensas matrimoniales, edad y oratorios.

Sobre Indias, solo se indicó que ni siquiera las de indulgencia podían ejecutarse sin autorización del Consejo de Indias (Rec. Ind. 1, 9, 2) ${ }^{110}$.

\footnotetext{
${ }^{104}$ Diario de las sesiones de las Cortes, IV, pp. 2.959 ss.

105 Ibíd., IV, pp. 2.673 ss.

106 Ibíd., IV, p. 2.674.

${ }^{107}$ Ibíd., IV, p. 2.688.

108 Ibíd.

109 Ibíd., IV, p. 2.689.

${ }^{110}$ Esta afirmación no se condice con lo planteado por Justo Donoso. El canonista chileno dijo que existía un pase regio o exequátur con muchísimas excepciones.
} 


\section{VISIONES CRÍTICAS FRENTE AL REAL PATRONATO Y AL} REGALISMO

Como ya se mencionó más arriba, el siglo XVIII vio nacer la doctrina de la separación de la Iglesia y el Estado, la que no fue ajena a América. En medio de las discusiones legislativas tendientes a determinar qué atribuciones tenía el Consejo de Regencia hubo voces que mediante cuestionamientos basados en las atribuciones indiscutidas del real patronato rechazaron la recepción de los postulados regalistas. Concretamente, lo que se discutió fue si el Consejo de Regencia era el órgano competente para nombrar empleados eclesiásticos. Los representes del regalismo estaban por la respuesta afirmativa. Fue Joaquín Fernández de Leiva, jurista chileno formado en la Real Universidad de San Felipe, quien cuestionó esa posición. Postuló que la única atribución que correspondía al Consejo de Regencia era presentar o proponer un candidato; pero tal propuesta en ningún caso obligaba a la Iglesia ${ }^{11}$. Continuó diciendo que el derecho de presentación era una de las mayores regalías con las que contaba la Corona. Dicha postura generó debate; pero no desvió el foco de la atención. De todas maneras, indica que, aún en posiciones minoritarias había grupos que propugnaban una mayor libertad religiosa. Su fundamento fue histórico. Se basaba en la práctica conocida como gobierno de los presentad os ${ }^{112}$. Llamativo es que dicha postura fuese planteada por el representante de una tradición jurídica marcadamente regalista.

No obstante, tal situación ya tenía precedentes en la América indiana. A medida que las políticas regalistas se hicieron más draconianas, especialmente durante el reinado de Carlos IV, surgieron voces dentro de la Iglesia indiana que clamaron por mayores grados de libertad. Tales posturas se manifestaron a raíz de situaciones muy concretas. El rechazo al regalismo se dio de manera subrepticia. El obispo de Puebla fue responsable de una de esas manifestaciones el año $1799^{113}$. Mediante carta dirigida al monarca protestó por la promulgación y aplicación de reales cédulas que despojaban a los eclesiásticos de su inmunidad en caso de cometer algún delito ${ }^{114}$. Su aplicación generó algunos tumultos, que atemorizaron al clero poblano. El obispo hizo presente que la Iglesia indiana había ejercido su ministerio en América en base a un estatus que ahora era abrogado. Fundamentaba la mantención de su estatus jurídico como una garantía de la autonomía, libertad e independencia para poder ejercer su labor salvadora. La fundamentación de esa

111 Diario de las sesiones de las Cortes, I, p. 205.

${ }^{112}$ Tal práctica consistía en que como el monarca no podía nombrar a las autoridades superiores de cada iglesia. Después de presentar un candidato a la Santa Sede, solicitaba al cabildo eclesiástico de la catedral que nombrase a esa persona de manera interina; pues el no tenía las atribuciones para hacerlo directamente. De esa forma, mediante un sistema de presión y contactos informales, la monarquía imponía a sus candidatos, dando muy poco margen de acción a la Santa Sede.

113 Véase el texto completo en DE LA HeRA, Alberto, Reforma de la Inmunidad personal del clero en indias bajo Carlos IV, en AHDE. (1960), pp. 553-616.

${ }^{114}$ Esas reales cédulas contenían normas que fueron redactadas con ocasión de la codificación de las leyes de indias conocidas como Código Carolino. Eran normas de un marcado énfasis regalista. 
autonomía o libertad está escrita en terminología indiana, ajena a toda abstracción basada en derechos o libertades. Habla de constitución, pero como la organización que cualquier sociedad se debe dar a sí misma, sin haber un nexo con el concepto que de este vocablo dio el constitucionalismo.

Dicha línea argumentativa recuerda de manera asidua a la voz justicia, como un reconocimiento a la labor de la Iglesia en material spiritual, como una matización de la idea de concesión graciosa del monarca. El rey no le concedió ese estatuto por bonhomía, sino porque la Iglesia se lo merecía. La voz justicia también es empleada como alusión a aquellos elementos perennes de la naturaleza humana, que se encuentran en toda persona, época y sociedad. Esa idea de justicia está muy cerca del concepto de de recho de gentes.

También emplea la voz justicia como sinónimo de dignidad, fundamento de lo que hoy se conoce como derechos fundamentales.

Esa alegación, vinculando la voz justicia con la tradición, desde el antiguo testamento y la ley judía hasta el derecho hispano e indiano, planteaba que las nuevas normas eran injustas por desconocer situaciones jurídicas e instituciones asentadas a lo largo del tiempo. Ellas son llamadas en esa carta "privilegio". Las normas que motivaron esa presentación derogaban esos privilegios, impedían la correcta evangelización y violentaban a la sociedad entera.

La idea de fondo del obispo poblano que debía existir una armonía entre la nueva legislación y aquellos principios e ideas generales del derecho vigentes a lo largo del tiempo.

Si bien no hay una mención formal a la separación de la Iglesia y el Estado, está dentro de los antecedentes que muestran el malestar latente ante la política regalista de Carlos IV, y que servirá de antecedentes para la larga discusión acerca del estatuto de la iglesia en las posteriores repúblicas latinoamericanas.

En resumen, el diputado chileno Joaquín Fernández de Leiva planteó tímidamente una opinión disonante, recurriendo al igual que el obispo poblano a las prácticas acaecidas en el transcurso del tiempo que ponían en duda la autenticidad de la doctrina regalista. Ambas intervenciones muestran que el regalismo fue una doctrina imperante pero no la única para abordar el milenario tema de la relación entre el poder temporal y el espiritual

\section{CONSIDERACIONES FINALES}

1. Como dice Carlos Salinas, a lo largo del siglo XIX el Estado confesional reemplazará al Estado misional en la América hispanoparlante ${ }^{115}$. En el papel, eso fue lo que ocurrió en la Constitución de Cádiz, mas no en los hechos, atendido a que por vía legislativa, el Estado misional siguió vivo, teniendo plena vigencia a través de instituciones como los curas de indios o doctrineros. Todas esas instituciones se vieron sujetas a un proceso de cambios propios del establecimiento

115 Salinas Araneda, Carlos, Las relaciones Iglesia-Estado en la América indiana: patronato, vicariato, regalismo, en ÉL MISMO, Estudios históricos. El Derecho canónico en Chile. Derecho canónico indiano (Valparaíso, Pontificia Universidad Católica de Valparaíso, 2014), p. 312. 
de un nuevo orden. Sin embargo, los fines evangelizadores siguieron presentes. Son reconocidos, aunque sin mención expresa en la carta fundamental.

2. El profesor Alberto de la Hera postula que durante el siglo XVIII el regalismo avanzó mucho más en ideas que en hechos. Las discusiones suscitadas en las Cortes dan cuenta de que, si bien las posturas regalistas estaban muy bien representadas, el hecho de no haberse promulgado el Código Carolino permitió hacer valer el derecho canónico indiano vigente, que no otorgaba tanta libertad de decisión a la Corona, ni había recepcionado el regalismo al nivel deseado por la Corona en la época de Carlos IV.

3. El derecho canónico indiano fue hecho valer en las Cortes. En algunos casos ni siquiera se discutió su validez o adecuación a los nuevos postulados. Simplemente se lo aplicó. El derecho canónico indiano gozaba de un alto grado de legitimidad social en América, como parte de la vida religiosa. Este derecho canónico invocado en las Cortes es esa rama del derecho indiano en su totalidad; es decir, aquel conjunto de normas que parte con las primeras decisiones de la reina Isabel la católica hasta aquellas contemporáneas a la convocatoria a las Cortes generales y extraordinarias. Esa larga vigencia del derecho canónico indiano explica la alegación de usos, prácticas y costumbres como norma vinculante. Aun siendo un derecho canónico con un marcado sentido de jerarquía y concentración de poder, en cuanto ordenamiento jurídico sirvió de freno ante intentos uniformadores que, en nombre de la igualdad y el constitucionalismo, intentaron plasmar en la ley y en la constitución una mayor concentración de poder, atentatoria contra la libertad mínima que la Iglesia necesitaba para cumplir con su labor.

4. Las discusiones muestran que efectivamente hubo un intento de cercenar las atribuciones de la Iglesia en aras de dar lugar a un derecho uniforme y unificador de corte estatal. Esos intentos se vieron frenados por la delicada situación política que atravesaba la Corona, por el derecho vigente - para el caso americano, el canónico indiano- y por una consideración sociológica a la legitimidad de la Iglesia en América. Esos intentos no nacen en las Cortes gaditanas, sino que hunden sus raíces en el regalismo borbónico del XVIII.

5. Las discusiones producidas por la apremiante situación económica y por la redacción de la constitución dan cuenta de que no hubo una sola interpretación para la relación Iglesia-Estado. Aunque tímida y minoritaria, la doctrina de la separación de la Iglesia y el Estado está representada en las Cortes, y por personeros del mundo indiano.

6. Existe un derecho canónico propio de las Indias, que se distinguirá por la especialidad de algunas de sus instituciones. Ese derecho está muy estatizado por la corona y se encuentra inherentemente unido al real patronato. Varias de esas instituciones son reconocidas en las Cortes en su dimensión jurídica y sociológica, como son los curas de indios y el obispado indiano.

7. Finalmente, real patronato y derecho canónico experimentaron en las Cortes una adaptación parcial al nuevo ordenamiento de corte constitucional. 


\section{BiBLIOGRAFÍA}

Aymans, Winfried und Mörsdorf, Klaus, Kanonisches Recht. Lehrbuch aufgrund des Codex Iuris Canonici (München, Ferdinand Schoningh, 1991).

Bravo Lira, Bernardino, Constitución y reconstitución. Historia del Estado en Iberoamérica (1511-2009) (Santiago de Chile, Abeledo Perrot.LegalPublishing, 2010).

Bravo Lira, Bernardino, El Estado misional, una institución propia del derecho indiano, en Estudios en honor de Alamiro de Ávila Martel. Anales de la Universidad de Chile, $5^{\text {a }}$ serie, $\mathrm{N}^{\circ} 20$ (1989).

Campenhausen, Axel Freiherr von und De Wall, Heinrich, Staatskirchenrecht $\left(4^{\circ}\right.$ Auflage, München, Verlag H. Beck, 2006).

De la Hera, Alberto, El artículo 12 de la Constitución de Cádizy la religión católica, en Escudero, José Antonio (ed.), Cortes y Constitución de Cádiz. 200 años (Madrid, Fundación Rafael del Pino, Editorial Espasa, 2011).

De la Hera, Alberto, El regalismo borbónico en su proyección indiana (Madrid, Ediciones Rialp S.A, 1963).

De la Hera, Alberto, Reforma de la inmunidad personal del clero en Indias bajo Carlos $I V$, en $A H D E$. (Madrid, 1960).

Donoso, Justo, Instituciones de derecho canónico americano escritas por el Rev. Sr. d. Justo Donoso (2a edición, Santiago de Chile, Librería de P. Yuste, 1861-1862).

Dougnac Rodríguez, Antonio, La producción canonista italiana en dos pensadores hispanoamericanos de comienzos del siglo XIX: el chileno Justo Donoso y el peruano Francisco de Paula González Vigil, en RChHD. 24 (2013-2014).

Dougnac Rodríguez, Antonio, Manual de historia del derecho indiano (2a edición, México, McGraw-Hill, 1998).

Egaña RISCO, Juan, Memoria política sobre si conviene a Chile la libertad de culto (Santiago de Chile, Imprenta de la Independencia, 1825).

Fioravanti, Maurizio, Constitución. De la antigüedad a nuestros días (2001, 2a edición, Madrid, Editorial Trotta, Bolonia, reimp, traducción castellana de Manuel Martínez Neira, 2011).

GarCía, José, Diario de las sesiones de las Cortes Generales y Extraordinarias: dieron principio el 24 de septiembre de 1810 y terminaron el 20 de septiembre de 1813 (Madrid, GarCía, José A. Impresor-editor, 1870).

Lorente, Marta y Portillo, José María (dirs), El momento gaditano. La Constitución en el orbe hispánico (1808-1826), en Colección Bicentenario de las Cortes de Cádiz (España, Congreso de Diputados. 2012).

Salinas Araneda, Carlos, Avance para una bibliografia chilena de historia del derecho indiano, en Él mismo, Estudios históricos. El derecho canónico en Chile. Derecho canónico indiano (Valparaíso, Pontificia Universidad Católica de Valparaíso, 2014), pp. 193-211.

SAlinas ARANEDA, Carlos, El derecho canónico indiano en la bibliografía de una década: apuntes para un balance, en ÉL MISMO, Estudios históricos. El derecho canónico en Chile. Derecho canónico indiano (Valparaíso, Pontificia Universidad Católica de Valparaíso, 2014), pp. 213-268.

Salinas Araneda, Carlos, Las relaciones Iglesia-Estado en la América indiana: patronato, vicariato, regalismo, en ÉL MISMO, Estudios históricos. El derecho canónico en Chile. Derecho canónico indiano (Valparaíso, Pontificia Universidad Católica de Valparaíso, 2014), pp. 279-313. 
Sánchez Bella, Ismael; De la Hera, Alberto; Díaz de Rementería, Carlos, Historia del derecho indiano, en Colección Relaciones entre España y América (Madrid, Editorial Mapfre, 1992). 